\title{
NARRATIVE AND STYLE - ESAÛ́ E JACó
}

\section{Muaray Graeme Macnicoll}

\section{A. INTERVENTIONS BY THE NARRATOR}

An author's style provides the reader with a unique insight into his literary personality. The prose style of Joaquim Maria Machado de Assis (1839-1908) is serious, cautious, pondering, and well organized. However, it is also capable of periodic interjections of humor and irony. Machado's literary personality emerges from the pages of Esaú e Jacó (1904), 1 his penultimate novel, by means of an omniscient narrator who intervenes regularly throughout the novel to pose questions, propose ideas, philosophize, and perform comic and ironic digressions.

The year 1878 marked a turning point in Machado's career. In April of that year he had published a two-part critique of the J. M. Eça de Queiroz' novle, O Primo Basílio (1878).2 In those articles Machado attacked the artistic validity of the Realist and Naturalist's approach to the novel. Then beginning in 1881, in what appeared to be a direct rebuttal to those two esthetic movements, he would publish five novels in his own extremely personal style. In them Machado challenged and negated the values of the Realist and Naturalist novelists of Portugal and Brazil.

In his last five works, Machado, antedating many twentieth- century novelists in his use of a variety of narrative and thematic innovations, demonstrated that man's primary preoccupations, such as truth, reality, and human existence, are acutely subjective literary and psychological concepts which readily vary with each individual's viewpoint. Unlike his Realist literary contemporaries, Machado did not pretend to possess or monopolize answers to truth, reality, and life. His final five novels are for he most part open-ended. Each of them purposely denies the traditional happy, or at least logical, ending, and is replete with numerous unanswered questions a void which the reader must fill, although not necessarily close, with his own imagination. Machado seemed to hold greater respect for his readers' intelligence than did his literary colleagues. He 
implied that truth, reality, and life, being experiences common to all individuals, the reader was to be obliged to participate along with the novelist in the seach, even though it be futile, for those essential answers.

The presence of a narrator in each of the final five novels, whether omniscient as in Quincas Borba (1891), or first-person participant in Memórias Póstumas de Brás Cubas (1881), Dom Casmurro (1899), and Memorial de Aires (1908), or as in Esaú e Jacó, where both types are present, strongly negated the doctrines and techniques of the Realists and Naturalists, whose literary creed obliged them to suppress all evidence of the author's presence.

Thus within Machado's novels Esaú e Jacó is unique due to its narration by both an omniscient author and a participant character, Counselor Aires. The latter, however, is dependent on the former, and, significantly, does not emerge as a narrator in his own right until Machado's final novel, Memorial de Aires. In Esaú e Jacó the Counselor is still within the control of the omniscient narrator. Consequently, the latter, in a manner alternately serious and humorous, strives to avoid censure for his own foolish and rhetorical remarks and frequently attributes them to the character Aires. For instance, it is Aires who is blamed for impishly modifying Padre Manuel Bernardes' celebrated phrase "Alonguei-me fugindo e morei na soedade" ( $p$. 82): "Aires trocou-lhe uma palavra e o sentido: Alonguei-me fugindo, e morei entre a gente" (p. 83). Machado as the narrator thus revives a quotation from the Classical Portuguese literature, deforms it in order to rejuvenate it, but attributes such literary license to anoher. And when he wishes to dissassociate the cultured Aires from commonplace statements, the omniscient narrator often invents an unidentified third person: "Pessoa a quem li confidencialmente o capitulo passado, escreve-me dizendo: 'A ocasião faz o ladrão"' (p. 166). The narrator at that point then attributed the upgrading of that heckneyed adage to the inventive Aires: "Uma das afirmações de Aires, quem também gostava de estudar adágios, é que esse não estava certo. A forma exata deve ser esta: 'A ocasião faz o furto, o ladrão nasce feito"' (p. 166).

Machado is observed maintaining various levels of association. Offstage or lesser characters in Esaú e Jacó are responsible for the statements or sayings which are most commonplace. Conversely, Aires often serves as an agent for Machado's humor by ridiculing, deforming, or upgrading such po- 
pular utterances. It is, however, Machado disguised as the omniscient narrator who reserves the most original, humorous, and sublimes interventions for himself; for example, references to classical literature or mythology: "Ulisses confessa a Alcinoos que the é enfadonho contar as mesmas cousas. Também a mim. Sou, porém, obrigado a elas, porque sem elas a nossa Flora seria menos Flora" (p. 207).

Having presented the above sketch of the several narrative levels of intervention, it remains to analyze the numerous types or categories of intervention. The approximately 150 interventions by the omniscient author in Esaú e Jacó can be divided into ten broad classifications:

(I) By far the most numerous are those which economize narrative time and space, permiting the novel to progress unhindered by voluminous details or exhaustive descriptions. It is of interest to note the relative brevity of Machado's novels: while those after 1881 average 180 to 230 pages, Machado's famous contemporary, Aluizio Azevedo, published novels which were a prolific 300 to 450 pages in length. Machado's narrator interventions which save time and printed space, substitute the Realist-Naturalist penchant for microscopic character descriptions, elaborate scenery, and graphic details. Concerned exclusively with human interiors and psychological motivation, Machado either discarded such encumbering external details or disposed of them in a single word or phrase.

Therefore, unconcerned with specific names, an exact time, place or activity, Machado simply omits the reference: "Não ficou o dia, o mês foi agosto" (p. 28); "para ir a não sei que compras" (p. 65); "Frei***. Podia escrever-Ihe o nome, ninguém mais o conheceria" ( $p$. 65).

In depicting the character Santos, who often spoke hastily and unintelligibly, Machado, avoiding a word-by-word portrayal as a Realist might have done, economizes both time and the reader's patience by summarizing: "As palavras de Santos sairam de atropelo, umas sobre outras, embrulhadas, sem princípio, sem fim" (p. 43).

In order to avoid excessive external descriptions and to concentrate closely on his primary preoccupations, Machado the narrator frequently will hasten the reader along, indirectly accounting for the passage of time: "Creio que já não existe" (p. 45), and imploring him or her not to ask questions or tarry: 
Não me peças a causa (p. 30) explicações comem tempo e papel (p. 31) nem comentário meu (p. 149) não me demoro em descrevê-lo (p. 46) causa tão particular que merecia ir em capítulo seu, mas não vai, por economia (p. 60) mas também outra que não digo por não valer a pena (p. 109) uma infinidade de cousas que não nomeio, para encher papel (p. 82) ainda outras que poupei ao leitor apressado (p. 112)

And with marked frankness the omniscient narrator declares that he simply cannot or will not provide further detail: "Não posso explicar" (p. 45).

Machado regularly reminds his reader that a given page or chapter should not be overburdened with words, sentences and ideas, lest it become excessively cluttered: "Se não fosse a necessidade de pôr os meninos em pé, crescidos e homens, espraiava este capítulo" (p. 55). At that juncture the narrator rapidly impels the twins through their early years:"uma página bastava para os chocalhos que embelezavam os pequenos" ( $p$. $55)$, and "a operação de desmamar podia fazer-se em meia linha... tudo isso exigia uma boa página ou mais" (p. 55). Machado the narrator on other occasions seeks gratitude from the reader for having spared him or her the tedious descriptions so common to the Realist and Naturalist schools: "Tudo isso restrinjó só para não enfadar a leitora curiosa de ver os meus meninos homens e acabados" (p. 55). Machado thus skips lightly over the twins' earlier years, realistically acknowledging the omitted time, but moving forward steadily to their early adulthood, where the principal action of Esaú e Jacó is concentrated: "Ei-los que vêm crescendo" (p. 56).

On certain occasions the reader is urged or invited to forego an entire chapter, if he wishes: "Não tendo outro lugar... aproveito este capítulo" (p. 65). In another instance Machado the narrator, instead of attempting to rival Plutarch regarding an especially beautiful phrase, achieves an equal effect by stating quite curtly: "Valia por um página de Plutarco" (p. 113). Another example of economy occurs when the narrator flatly refuses to develop a point: "Esse ponto, no nosso caso, não pode ser ventilado, nem eu quero desenvolvê-lo, como aliás cumpria" (p. 132). The narrator also admits (p. 148) that he scratches out or erases words and admonishes the reader not to try to resuscitate them. 
In another case the narrator cleverly avoids duplicating a psychological description of the twins, Pedro and Paulo. After delving at length into Paulo's soul (p. 177), Machado economizes space, foregoing a similar long-winded probe into Pedro's soul by stating flatly: "[a alma de Pedro] era gêmea da outra; não the viu mais nem menos que nesta" (p. 178).

The Realist and Naturalist insistence on minute portrayals of characters, clothing and milieu was emphatically rejected by Machado: "Crede-me que eu preferia contar as rendas do roupão da moça... seria enfadonho, mas entendia-se" (p. 178). Again, perhaps having his feminine readers in mind and recalling the excesses he had criticized in O Primo Basilio, Machado the narrator intervenes to spare the reader from harsh and ugly words uttered to each other by the twins (p. 182).

Toward the final chapters of Esaú e Jacó, Machado the narrator astutely senses the reader's weariness, and hints at the approaching finale: "Se não fora o que aconteceu e se contará por essas páginas adiante, haveria matéria para não acabar mais o livro" (p. 185). From that point forward the narrator increases the pace of the novel and brings it to a rapid end: "Assim como o carro veio voando do cemitério, assim voará este capítulo... voe este capítulo, como o trem de Mauá" (p. 219). The narrator quickly ties together the thoughts of the personage Natividade prior to her death: "vou aqui resumindo, como posso, as esperanças de Natividade" (p. 221). Finally, there are two interventions which contribute to the atmosphere of finality: "Não é a primeira vez que o digo, mas provavelmente a última" (p. 226), and "descansas, amigo, não repito as páginas" (p. 231).

(II) Another category of intervention often occurring in Esaú e Jacó is a technique designated by Maria Nazaré Lins Soares ${ }^{3}$ as "dizer não dizendo." An example of this stylistic device which employs both denial and negation occurs immediately in Chapter I, during the visit by Natividade and Perpétua to the fortune teller's shack. The narrator, although constantly apologizing for his avoidance of minute descriptions, imparts indirectly to the reader a vigorous description by means of denial. Note the spooky tone attained in the following passage:

conduziu as senhoras à sala. Esta era simples, as paredes nuas, nada que lembrasse mistério ou incutisse pavor, nenhum petrecho 
simbólico, nenhum bicho empalhado, esqueleto ou desenho de aleijões. (p. 20)

Following a symmetrical description of two horses, "os próprios cavalos eram iguaizinhos, quase gêmeos, e batiam as patas com o mesmo ritmo, a mesma força e a mesma graça" (p. 74), Machado the narrator then indirectly emphasizes the above harmony by denying any further extension of that same symmetry to tails and manes: "não creias que o gesto da cauda e das crinas fosse simultâneo nos dous animais: não é verdade e pode fazer duvidar do resto. Pois o resto é certo" (p. 74). The narrator also offers slight denials of the reality of semipoetical statements; however, in so doing the poetic impression is further enhanced: "O céu parecia escrever o tratado de paz que ambos teriam de assinar... Também não juro isto, digo o que se pode crer só pelo aspecto das cousas"' (p. 189).

In another example, Machado, assiduously avoiding lengthy descriptions, again portrays indirectly, now using a negative sentence: "Não se descreve a admiração do secretário, em seguida a consternação, finalmente a indignação" (p. 211). He also makes a flat denial in another case, by attributing the origin of a particular statement to a personage, disavowing responsibility, but permitting the declaration to stand: "Não sou eu que o digo: Santos é o que pensou" (p. 31). Often the narrator confesses to not having used the appropriate word or term, seemingly casting doubt on his own veracity, which contributes even further to the murky Machadian intent: "embora esta palavra não exprima exatamente o que quero dizer" ( $p$. 47). Machado also continues the proceess, "dizer não dizendo," by refusing to commit to paper what he believes obvious: "Não digo com isto... cousa tão óbvia que custa escrever" (p. 46). Such denials, refusals, and negatives are abundant throughout Esaú e Jacó. All of them, however, evoke an understanding on the reader's part, and, more significantly, oblige him or her to participate closely in the development of the novel.

(III) A third category of interest is the series of narrative interventions which attempts to scrutinize human sentiment, the human psyche, and the processes of thought. Machado's efforts to penetrate the workings of the mind years before the divulgation of Freud in Brazil further make salient the author's rejection of the Realist and Naturalist's penchant for exterior observation, and his own success in creating a singular novelistic style. Delving into the human psyche ("O homem é um alfabeto de sensaçöes," (p. 174), Machado illustrated psycho- 
logical actions: "Velhas idéias... emergindo do cérebro e descendo ao coração" (p. 40), portrayed the thought process: "A palavra rasgava-lhe o cérebro, ferindo sem penetrar" (p. 83), or the groping of the mind: "apalpava-se moralmente" (p. 106). Machado implied that existence is too infinitely complex and profound to be systematically sketched by literature: "Mas no secreto do coração, lá muito ao fundo, onde não penetra olho de homem" (p. 59); and "o olho do homem serve de fotografia ao invisível, como o ouvido serve de eco ao silêncio" (p. 96). In another often-cited example, which juxtaposes psychology and physiology, Machado strives toward a graphic visualization of the manner in which the learned mind functions:

O leitor atento, verdadeiramente ruminante, tem quatro estômagos no cérebro, e por eles faz passar e repassar os atos e os fatos (p. 128) um dia, a língua deu sete voltas na boca, e o segredo saiu medroso e sussurado. (p. 180)

Two final portrayals in this vein are the temporary departure of Flora's communicative soul: "A viagem que o espírito da moça fazia à casa da gente Santos... voltou para dizer estas palavras ao coração: quem és tu que não atas nem desatas" (p. 194), and the personification of secrets: "Então, pedem [os segredos] aos deuses (porque os segredos são pagãos)... que os segredos, minha amiga, são gente, vivem e morrem" (p. 192).

(IV) From a fourth series of interventions the narrator derives an odd synthesis of humorous teasing and suspense: "Não ponho aqui... não te minto" (p. 21), "custa-me dizer" (p. 22), "se minto, não é de intenção" (p. 27), "não concluas daqui" (p. 43), "esqueceu-me dizer que" (p. 43), and "não posso explicar" (p. 45); there are also ironic parallels: "não digo que sim, nein que não" (p. 30). Machado frequently sustains the reader's attention by withholding facts or information, promising to explain later: "quanto à matéria da conspiração, podereis sabê-la depois, brevemente, daqui a um capítulo" (p. 118). In another instance, a humorous rhyme is reemphasized by an additional comment from the narrator: "as ocasiões fazem as revoluções, disse ele, sem intenção de rimar, mas gostou que rimasse, para dar forma fixa à idéia" (p. 146). In the last example, Machado ventures a rare comment concerning North Americans, turning his teasing humor against the Yankee inventor type of New England: "[no futuro] Quanto à comida, 
virá de Boston ou de Nova lorque um processo para que a gente se nutra com a simples respiração do ar" (p. 197).

(V) In a fifth group of interventions are observed the narrator's preoccupation, at times obsessive, with the mechanics of composition and writing. In one instance, capital letters are humorously discussed in the case of the abstract noun "Modéstia," as to whether it wishes to have a capitalized "M." The comma is cited: "Daqui a dizer que ambos a amavam era uma vírgula" (p. 119). The narrator's acute awareness of rhetorical devices is frequently evident in the text of Esaú e Jacó: "Não falo só por imagem... amava as imagens graciosas e aquela pareceu-lhe graciosíssima" (p. 105). At times the narrator criticizes the images of his own or of the personages' creation: "[duas lágrimas] como outras tantas fitas que lhe atavam para sempre à pasta do passado. A imagem não é boa, nem verdadeira; foi a que acudiu ao conselheiro" (p. 205). In another intervention the narrator apologizes for lacking the time to seek out a better figure: "Perdoa a figura; não é nobre, nem clara, mas a situação não me dá tempo de ir à cata de outra" (p. 177). Machado's acute consciousness concerning the demands of refined and responsible composition appears in the text in another instance regarding an unsubstantiated opinion: "mas não possuo o menor documento disto" (p. 86).

The narrator also evidences his foresight concerning the placement and organization of chapters. The closely interwoven structure of Esaú e Jacó and other Machadian novels can in part be attributed to constant citings and references to previous and sometimes even later chapters: "Sei que este fenômeno é tal qual o do capítulo XXV"' (p. 87). In Chapter XCIX the narrator refers twice to Chapter XXXII, "O Aposentado." An audacious innovation, chapters in which only other chapters are discussed, occurs in Chapter CXIX, "Penúltimo," wherein the entire chapter is devoted to an announcement that there will be two final chapters, "Penúltimo" and "Último." A humorous and playful trick is employed to connect two chapters: [Chapter $\mathrm{XCIX]} \mathrm{"E} \mathrm{daí} \mathrm{outro} \mathrm{abraço} \mathrm{longo,} \mathrm{mais} \mathrm{longo...} \mathrm{[Chapter} \mathrm{C]}$ Tão longo foi o abraço que tomou o resto ao capítulo" (p. 204).

Such an intense preoccipation with the mechanics of composition and style would have comprised a literary taboo to Machado's Realist-Naturalist contemporaries.

(VI) In somewhat the same vein as the previous group are the interventions which criticize and belittle the stylistic short- 
comings and pretensions of individual personages. The latter are often ridiculous secondary characters and certain stereotypes such as poets, politicians, and newspaper writers, who receive the brunt of Machado's acidic criticism of hackneyed style. For example, the amateur poet Gouveia: "gastava papel e tinta a metrificar as esperanças. Os versos escorriam da pena, a rima, com eles, e as estrofes vinham seguindo direitas e alinhadas, como companhias de batalhão" (p. 198). The same Gouveia in his love letter to Flora typifies governmental bureaucratese: "Saiu-lhe ao estilo das informações e dos ofícios, grave, respeitoso, com excelências" (p. 198).

Another genre of composition which Machado attacked with noticeable delight was the political manifesto, which he perceived to be structured according to a commonly accepted recipe:

Batista recordou o tempo dos manifesto liberais, e quis fazer um. Chegou a principiá-lo, em segredo, empregando as belas frases que trazia de cor, citações latinas, duas ou três apóstrofes. (p. 158)

The narrator scornfully relegates the character Nóbrega to a position inferior even to the other mediocre writers and poets of Esaú e Jacó, by exposing his total incapacity to compose even a rudimentary prose: "Sabia pouca ortografia, nenhuma sintaxe, lições úteis... uma carta supria tudo, mas a carta pedia língua, calor e respeito"' (p. 208).

A final example of Machado the narrator's awareness of the techniques and problems of composition is a marked fear of lapsing into an "excessive" style. Here a seulf-criticism in parentheses follows a short passage of what Machado considered the shopworn eloquence of his time: "Que esse breve raio de luz lhe desabotoasse as flores da esperança (começo a falar como a primeira carta)" (p. 198).

(VII) A seventh category of interventions consists of quotations. For the most part such quotations are digressions which assist the narrator in illustrating, expanding, or reinforcing a particular point or idea. Some quotations are commonplace expressions which Machado frequently deforms, in order to reinvigorate their communicative value. All of Esaú e Jacó's mediocre personages are totally unoriginal and, as a consequence, borrow expressions from a common and tired patrimony: "Tal- 
vez essas razões não fossem propriamente dela, mas ouvidas a alguém, decoradas sem esforço e repetidas com convicção" (p. 35).

The narrator often takes a commonplace expression, and, after carefully attributing its origin to others, deforms it for a humorous effect: "Pessoas do tempo, querendo exagerar a riqueza, dizem que o dinheiro brotava do céu" (p. 162). In other cases Machado simply repeats an adage, applying it to a specific character: "Há pessoas para quem o adágio que diz 'o melhor da festa é esperar por ela,' resume todo o prazer da vida. D. Rita tinha esta opinião" (p. 209).

When Conselheiro Aires as narrator intervenes (p. 76) to remake an expression in Spanish, Machado the narrator endows the ensuing result with an abundance of "issimos" to ironize Aires' endeavor. Later the Conselheiro refers to a Greek saying in its entirety, "a guerra é mãe da todas as cousas" (p. 50), but deforms it by applying it to Love. Another deformed proverb provided an opportunity for Machado to philosophize concerning the utilization of proverbs:

'Quando um não quer, dois não brigam.' $\mathrm{Na}$ idade madura eles [provérbios] devem já fazer parte da bagagem da vida, frutos da experiência antiga e comum... Troca de fórmula: 'Se nenhum quer, nenhum briga' (p. 220)

Furthermore, with respect to the statement "Resta emancipar o branco" (p. 89), Machado digresses on the formation of proverbs and commonplace forms: "Era nova, era enérgica, era expressiva, ficou sendo patrimônio comum" (p. 89). Also deformed in Esaú e Jacó were phrases from Caesar and the Portuguese chronicler Zurara: "César ou João Fernandes" ( $p$. 34). Buffon's phrase "Le style est l'homme même" is rearranged to "O estilo não é o homem" (p. 157). These last demonstrate Machado's impressive knowledge of classical literatures.

(VIII) A less frequent category is comprised of interventions aimed directly at the reader ("leitor" and "leitora"). Some in this grouping invite the reader's participation in the novel's action: "Talvez a leitora, no mesmo caso, ficasse aguardando o destino" (p. 40). On another occasion the narrator warns the reader, especially those expecting a Romantic novel, not to tamper with the novel's structure: 
Aqui entra uma reflexão da leitora. $O$ que a senhora deseja, amiga minha, é chegar já ao capítulo do amor ou dos amores. Francamente, eu não gosto de gente que venha adivinhando e compondo um livro que está sendo escrito com método. Se quer compor o livro, aqui tem a pena, aqui tem o papel, aqui tem um admirador. (p. 73)

A final example to be noted occurs when Machado addresses the reader as an abstract entity, perhaps simultaneously and indirectly lamenting the sparse Brazilian reading public of the time: "Não sei quem me lê nesta ocasião' '(p. 93).

(IX) A final category is composed of philosophical interventions in which the narrator ruminates on questions of truth, reality, and life. None of these statements by Machado is intended to be absolute, and all remain open-ended. This attitude and approach again make salient the void between Machado and his contemporaries, whose theories and doctrines presupposed absolute truths and factual reality. The famous "dúvida machadiana" stems in part from this very denial of absolutes.

Machado specified that Time can alter Truth: "Nem todas seriam estritamente exatas: o tempo é roedor das coisas, que as diminui ou altera no sentido de Ihes dar outro aspecto" (p. 63). The novelist theorizes that Truth depends as well on the perceptive powers of the observer:

Há, nos mais graves acontecimentos, muitos pormenores que se perdem, outros que a imaginação inventa para suprir os perdidos, e nem por isso a história morre (p. 63). Não há memória que dure. (p. 96)

And while denying any absolutes, Machado creates a serious and gloomy humor:

Mas diga-me o que é que há definitivo neste mundo a não ser o voltarete de seu marido? (p. 90)... era difícil atinar com a verdade. A única verdade certa eram os dous mil-réis ( $p$. 166)... já o [Aires] tenho achado em contradição. Pode ser. A vida e o mundo não são outra coisa. (p. 183) 
Machado's personal philosophies are glimpsed briefly on other occasions, some of which are humorous: "Na mulher, o sexo corrige a banalidade; no homem, agrava" (p. 79), and " 'Pois podem contá-lo a mim. Eu seria discreto como um túmulo.' Aires sabia que os túmulos não são discretos" (p. 232).

Two additional interventions witness what seems to be a softening of Machado's earlier pessimism, possibly a conciliation with life and a preview of the tone of inner peace which characterize Memorial de Aires in 1908. For instance, that pain and adversity may have positive aspects:

A dor os fez amigos por instantes: é uma das vantagens dessa grande e nobre sensação (p. 131)... não há mal que não traga um pouco de bem, e por isso é que o mal é útil, muitas vezes indispensável, alguma vez delicioso ( $p$. 133).

Esaú e Jacó demonstrates Machado at the zenith of his role as narrator-author. This eighth novel is replete with interventions, the most salient of which have been discussed herein. Except for the part-time narrator Conselheiro Aires, no personage in the novel is developed to the point where he might rival the narrator's central vantage point. In fact, the characters of this penultimate novel are mere wo-dimensional figures, created to cloth Machado's philosophies, ideas, humor, stylistic preoccupations and denial of absolutes.

\section{B. DESCRIPTIVE STYLISTIC TECHNIQUES}

Since Brás Cubas, Quincas Borba, and Dom Casmurro are to a greater degree profound studies of human nature, they exhibit a lesser utilization than Esaú e Jacó of what may be considered descriptive stylistic elements. In this eighth novel there is a marked focus on external appearance, which in turn affords Machado ample opportunity to explore and perfect style as a descriptive device.

\section{Simmetry}

The basic theme of Esaú e Jacó, the quest for human perfection, is symbolized by the polarized twins, Pedro and Paulo. Their presence enables the methodical Machado to experiment with symmetrical description. Symmetry often emerges in scenes when the twins appear together: 
Paulo era mais agressivo, Pedro mais dissimulado. (p. 56)

[Paulo] Nasci no aniversário do dia em que Pedro I caiu do trono. [Pedro] Nasci no aniversário do dia em que sua majestade subiu ao trono. (p. 64)

Não se dão ou se dão mal. (p. 73)

Paulo gostava mais de conversa que do piano. Pedro ia mais como o piano que com a conversa. (p. 83)

A alegria vinha da prontidão de Paulo, a tristeza da ausência de Pedro. (p. 175)

O mesmo conflito de afinidades, o mesmo equilibrio de preferências. (p. 194)

No valor e no ímpeto podia comparar o coração ao gêmeo Paulo. O espírito, pela arte e sutileza, seria o gêmeo Pedro. (p. 195)

Se podiam, não comiam juntos; se comiam juntos, diziam pouco ou nada. (p. 195)

Ambos apoiavam a república, mas Paulo queria mais do que ela era, e Pedro achava sue era bastante e sobeja. (p. 228)

Tal era a união, que pareciam aposta. Entravam juntos, andavam juntos, saiam juntos. Duas ou três vezes votaram juntos. (p. 234)

\section{Verbs}

On one occasion Machado's symmetry becomes ironic hyperbole: "eram ambos gulosos, Pedro mais que Paulo, e Paulo mais que ninguém (p. 56). Such symmetry is frequently employed for emphasis: "Toda uma questão de número, menos que número, o nome" ( pleteness: "a fé era viva, a afeição segura, a paciência infinita" (p. 65). In another example of symmetry, Machado humorously portrays painters who work endlessly: "botam tinta, mais tinta, outra tinta, muita tinta, pouca tinta, nova tinta" (p. 84). In 
other instances, the narrator utilizees symmetry to depict methodical individuals such as Conselheiro Aires: "abriu uma gaveta, tirou uma pasta, abriu a pasta, tirou o documento" (p. 9 123). Symmetry also describes the perfection of Santos' coachmen, and the wellordered world of the prosperous banker: "cocheiros e laicos, barbeados e graves, esperando tesos e compostos" (p. 163). It is used to portray the stability neutrality and aclm of the city of Petrópolis, especially in contrast to the turmoil of Rio de Janeiro during the 1890's: "Petrópolis é a cidade da paz... é a cidade neutra, é a cidade das nações" (p. 191).

Although Machado's style has often been held to be flat and colorless, Esaú e Jacó presents the reader with an array of descriptive technical devices which provide it vivid notes of realism. Machado's selection of verbs graphically depicts movement and evokes mental pictures. He frequently groups verbs in threes or fours to portray prolonged action, or to extend particular scenes: e.g., prolonged action, imperfect tense: "e fitava-as, e cheirava-as, e escutava-as" (p. 26); and, e.g., future hope: "eles hão de subir, subir, subir" (p. 23). In another humorous instance, the preterit was expeditiously used to dispose of an impoverished, unwanted relative who had journeyed to Rio de Janeiro from the province for a hand-out: "arranjou-lhe depressa... despachou-o" (p. 30). Following their clandestine visit to the fortune-teller of the Morro do Castelo, Natividade and Perpétua fear being recognized and subsequently desire to exit rapidly. The latter action is conveyed aptly by five verbs in the preterit: "visto que subiram, que desceram, deram os dois mil-réis, entraram no carro e voltaram para Botafogo" ( $p$. 40). Hastiness in making a decision also demanded the preterit: "propuseram, discutiram, emendaram e concluiram" ( $p$. 189). In Chapter CXII, in an extreme case, the narrator chose three sets in "ternário" to intensify Paulo's actions and thoughts in the cemetary: "estacou, recuou, e novamente se escondeu... aceitando, repelindo, esperando... arredou-se, desceu e saiu" (pp. 222-223).

To animate the image of the "hipótese andorinha," Machado utilizes a cluster of verbs in the present tense: "chegou a apanhar uma hipótese, espécie de andorinha, que avoaça entre avores, abaixo e acima, pousa aqui, pousa ali, arranca de novo um surto e toda se despeja em movimentos" (p. 97). Machado also selects a series of vivid verbs to transmit the external manifestations of Batista's political anguish: "Que em se ca- 
lando, coçava a cabeça, apertava as mãos ou suspirava, quando não ameaçava o teto" (p. 154).

\section{Gerunds}

Gerunds appear in sets of three and four to depict wandering speech: "a boca ia falando, mandando, chamando e rindo" (p. 43), or to capture a vivid atmosphere of hubbub in a drawing room: "conservando, calando, mirando" (p. 62). A series of four gerund-infinitives, grouped by twos, prolongs the narrative and graphically demonstrates Flora's insomnia: "à janela ou sentada, a recordar e a pensar, a cotejar e a completar" (p. 176). Flora's hallucination, conversely, is introduced by two pairs of infinitives: "era muito fazer e desfazer, mudar e transmudar" (p. 178). Machado repeats the verb "brigar" four times in one paragraph (p. 44) to emphasize the twins' grave emnity.

\section{Pronouns:}

Machado insits on the use of numerous pronouns, especially enclitic, which intensify the psychological impact of certain phrases: "era um recreio procurá-las, achá-las, e completá-las" (p. 82), and "ouvi-la, cheirá-la, gostá-la, apalpá-la" ( $p$. 83).

\section{Nouns:}

Nouns likewise contribute to the graphic and animated prose of Esaú e Jacó. The greedy banker Santos imagines a scene of extreme opulence, reminiscent of Machado's literary contemporaries, the Symbolists: "Oh! Gozo infinito! Santos imaginava os bronzes, mármores, luzes, flores, danças, carruagens, músicas, ceias" (p. 42). Another richly-drawn passage describes the horses of the goddess Juno: "as aparelhara com suas correias de ouro, freios de ouro, rédeas de ouro, tudo de ouro incorruptivel" (p. 92). As in the earlier illustration of verbs, nouns also are repeated in threes and fours for emphasis: "não confiava de homem aquele passado, mas às paredes mudas, às grades velhas, às portas gretadas, aos lampiōes antigos" ( $p$. 165); and "Pedro e Paulo falavam-lhe por exclamaçōes, por exortações, por súplicas" (p. 178).

In the last paragraph of Chapter LXXIX and the first line of Chapter LXXX, Machado appropriately weaves a passage of vague nouns, in order to intensify a diaphanous atmosphere: 
"Era um espetáculo misterioso, vago, obscuro, em que as figuras visiveis se faziam impalpáveis, o dobrado fica único, o único dobrado, uma fusão, um confusão, uma difusão... [Chapter LXXX] Uma transfusão..." (p. 172).

On other occasions the narrator purposely avoids logic and congregates disparate nouns to form scenes of disorder, thereby heightening the animative effect: "toda a terminologia espírita saiu fora, e mais os casos, fenômenos, mistérios, testemunhos, atestados verbais e escritos" (p. 49).

\section{Adjectives:}

Groups of adjectives, some as nouns, likewise serve to increase the descriptive impact of Machado's portrayals: "o íngreme, o desigual, o mal-calçado da ladeira mortificava os pés às duas pobres donas" (p. 19); and "subia-se por uma escadinha, estreita, sombria, adequada à aventura" (p. 20). Sometimes the effectiveness of the adjectives is increased through symmetry: "próxima no tempo... remota no espaço" (p. 132); or rhyme: "criaturinha leve e breve" (p. 21), and "não querendo dar a resposta nua e crua" (p. 210). The author frequently employs diametrically contrasting adjectives to awaken or jar the reader's sensitivity: "tão humana e tão fora do mundo, tão etérea e tão ambiciosa" (p. 134), and "era uma mistura de opressivo e delicioso, de turvo e claro, uma felicidade truncada, uma aflição consoladora" (p. 168). In another case such contrasting adjectives indicate Flora's complicated state of health: "o rosto pólido, os olhos fundos, as mãos quentes" (p. 213). Elsewhere the tedium of ideas is reinforced by appropriate adjectives: "as idéias se iam tornando esgarçadas, nevoentas e repetidas" (p. 152). In two final examples, it is noted that Machado's adjectives may transpose animate or human capabilities to inanimate objects: "[moedas] azinhavradas e tristes" (p. 26), and "[Dona Cláudia] ficou esperando ansiosa. Esperou duas mortais horas" (p. 170).

\section{Adverbs:}

Machado less frequently endowed adverbs with such pictorial missions, but some examples do appear in Esaú e Jacó. There is one six-syllable adverb which depicts slow and hesitant movements: "e vinha a repeti-la consigo, va/ga/ro/sa/men/ te, como ia andando" (p. 96), and "Paulo, va/ga/ro/sa/men/te, caminhou para a sepultura" (p. 221). In another descriptive vein, Machado provokes a definite psychological nuance by contras- 
ting one adverb which expresses duration of time with another, of emotion, thus heightening the evocative potential of the phrase: "pedindo longa e lastimosamente" (p. 26).

\section{Onomatopeia:}

In other instances, subtle touches of onomatopeia are inserted to increase the audial and poetic potential of several scenes; ominous: "um mar TORvo, soTURNO, ONde as VOZes do infinito se perdiam" (p. 53); lugubrious: "descendo o caixão à cova... com aquele BAQue soTURNO... com aquele VAGAR CANsativo"' (p. 82); charming: "toda a andorinha que se dispersava num FARFALHAR calado de GESTos" (p. 97).

\section{Negatives:}

Machado evidences as well a marked predilection for emphatic negatives. As many as eight are to be found in a single sentence: "Quisera NÃO ver NADA, NEM passado, NEM presente, NEM futuro, NÃO saber de homens NEM de coisas, e obedecer aos dados da sorte, mas NÃO podia" (p. 106); or in groups of four, as in underlining Flora's curt refusal of Nóbrega's marriage proposal: "e NADA, NADA, NADA, absolutamente NADA, uma simples recusa" (p. 211). On another occasion, not content with a simple negative word, Machado makes use of physical motion: "a cabeça e o dedo sublinhavam a negativa" (p. 213).

\section{Metaphors and Images:}

Among the more interesting metaphors and images are two which augment the descriptive powers of Machado's style: "um dia dobrou a esquina da vida e caiu na praça da morte" (p. 66); and in the phrase "o Cabo das Tormentas converteu-se em Cabo da Boa Esperança" (p. 59-60), Portuguese history is utilized to digress on the topic of Natividade's fortieth birthday. Further examples, although sensitively poetic, still convey an intense picture: "até que o sono entrou com os seus pés de lã e bico calado, e tomou conta da alcova inteira" (p. 58).

\section{Collective Scenes:}

The final example to be considered, that of the collective scene, is especially utilized in Esaú e Jacó in comparison with Machado's previous fiction. This novel can be considered the most "Brazilian" of Machado's nine, inasmuch as an inordinate 
effort has been made to insert scores of references to Brazil's history, economy, literature and political figures. The principal action of Esaú e Jacó occurs between 1888 and 1894, a tumultuous period in Brazilian history which Machado is especially successful in capturing. For exampel, during the Republican Revolution of November 15, 1889, Machado, in this novel, foregoes an attempt to describe directly the triumph of Deodoro da Fonseca in the Praça da República. Instead, the novelist conveys a vivid impression of the public confusion and bewilderment by synthesizing rumors from the street:

Ouviu umas palavras soltas, 'Deodoro,' 'batalhões,' 'campo,' 'ministério,' etc. . . mas nenhuma noticia clara nem completa... Falou de uma revolução, de dois ministros mortos, um fugido, os demais presos. O imperador capturado em Petrópolis, vinha descendo a serra. ( $p$. 137)

Later, the encilhamento, a financial tornado which snarled Republican Brazil's economy during the early eighteen-nineties, is depicted by means of an appropriately chaotic paragraf which merits transcription:

Cascatas de idéias, de invenções, de concessões rolavam todos os dias, sonoras e vistosas para se fazerem contos de réis, centenas de contos, milhares, milhares de milhares, milhares de milhares de milhares de contos de réis. Todos os papéis, aliás ações, saiam frescos e eternos do prelo. Eram estradas de ferro, bancos, fábricas, minas, estaleiros, navegação, edificação, exportação, importação, ensaques, empréstimos, todas as uniões, todas as regiões. (p. 161)

Unlike Machado's other novels, Esaú e Jacó is replete with numerous popular scenes. He describes the teeming multitudes of social types on the Morro do Castelo: "a manhã trazia certo movimento; mulheres, homens, crianças que desciam ou subiam, lavadeiras e soldados, alguns empregados, algum lojista, algum padre" (p. 20); and the disorder of the Morro: "as camisas penduradas às janelas, as cascas de banana no chão" (p. 24). A slight note of commiseration is discerned during the scene showing the humble worshippers at the Igreja de São Domingos: "às outras missas vieram vindo, todas a pé, algu- 
mas de sapato roto, não raras descalçadas, capinhas velhas, morins estragados, missas de chita, ao domingo missas de tamanco" (p. 29).

Machado de Assis in Esaú e Jacó reached a maturity of style and a narrative serenity which had been absent during his earlier years. By 1904, already in his mid-sixties, the Brazilian novelist had visibly resigned himself to the vicissitudes of life. Instead of continuing his concentration on the human psyche, Machado, in this eighth novel, painted a panorama of late nineteenth-century Brazil. He simultaneously sought out stylistic perfection by means of the technique of narrator intervention, as well as with a considerable input of descriptive stylistic devices. Machado attained a maximum level of literary expression while painting an intense mural of the epoch. The critic Silvio Romero had, in his study Machado de Assis (1897), loudly complained that Machado ignored and omitted the Brazilian milieu from his novels. Esaú e Jacó, teeming with a vibrant and colorful turn-of-the-century Brazil, would appear to be an artist's response to a critic's lament.

\section{FOOTNOTES}

1 J. M. Machado de Assis, Esaú e Jacó (Rio de Janeiro: Garnier, 1904); all quotations are from the edition published by Cultrix (São Paulo, 1961), edited by Massaud Moisés.

2 See J. M. Machado de Assis, "Literatura Realista - o Primo Basilio, romance do Sr. Eça de Queiroz - Porto - 1878," o Cruzeiro (Rio de Janeiro), April 16 \& $30,1878$.

3 See Maria Nazaré Lins Soares, Machado de Assis e a Análise de Expressão (Rio de Janeiro: Instituto Nacional do Livro, 1968).

Luzo - Brazilian Center

University of Wisconsin

Madison, Wisconsin 53706 - USA 